\title{
Alveolar Distraction Osteogenesis
}

\author{
Deepika Masurkar¹, Priyanka Jaiswal2 ${ }^{2}$, Diksha Agrawal ${ }^{3}$ \\ 1, 2, 3 Department of Periodontics, Sharad Pawar Dental College, Datta Meghe Institute of Medical \\ Sciences, Sawangi (Meghe), Wardha, Maharashtra, India.
}

\begin{abstract}
Resorbed alveolar ridges, which can be horizontal or vertical in size, are one of the most prevalent issues addressed by dental experts. One of the therapy options for addressing the weak sections of the alveolar ridges is alveolar distraction osteogenesis. Alveolar distraction osteogenesis is a biological process that includes gradual traction between vascularized bone segments in order to generate new bone. Typically, an osteotomy is done, followed by the placement of an osteodistraction device to manage the separating process. This approach eliminates the need for bone grafts by producing the same quality and shape of bone. Distraction osteogenesis (DO) causes soft tissue to develop as new bone is formed on the deficient ridge. Because this treatment restores bone height, lengthier dental implants can be placed. In this work, we cover ride augmentation and the numerous procedures used to repair a resorbed alveolar ridge. It emphasises the relevance of alveolar distraction osteogenesis and provides a brief history of the procedure based on existing information. To summarise, distraction osteogenesis proved efficient in increasing the alveolar ridge and ensuring dental implant recovery.
\end{abstract}

\section{KEY WORDS}

Distraction osteogenesis, stages of distraction osteogenesis, advantages and disadvantages of distraction osteogenesis.
Corresponding Author: Dr. Deepika Masurkar, Department of Periodontics, Sharad Pawar Dental College, Datta Meghe Institute of Medical Sciences, Sawangi (Meghe), Wardha, Maharashtra, India. E-mail: dipika.masurkar@gmail.com

DOI: $10.14260 / \mathrm{jemds} / 2021 / 701$

How to Cite This Article:

Masurkar D, Jaiswal P, Agrawal D. Alveolar distraction osteogenesis. J Evolution Med Dent Sci 2021;10(38):3462-3465, DOI: 10.14260/jemds/2021/701

Submission 19-03-2021, Peer Review 05-09-2021, Acceptance 11-09-2021, Published 20-09-2021.

Copyright (C) 2021 JEMDS. This is an open access article distributed under Creative Commons Attribution License [Attribution 4.0 International (CC BY 4.0)] 


\section{BACKGROUND}

In 1981, Branemark ${ }^{1}$ presented a novel dental modality that is titanium dental implant (machined), a novel way to manage missing teeth. Survival rate of nearly $95 \%$ in systematically healthy patients of dental implants was reported (den Hartog $\mathrm{L}$ et al. 2008). ${ }^{2}$ Thus dental implants are considered a dependable treatment modality for individuals with missing one or many teeth. Though, unfavourable situations such as extraction, trauma or periodontitis cause reduction in the alveolar bone, which can led to disturbed inter-arch relation in all the planes, and improper placement of dental implant from an aesthetic and functional prospective. Thus, for the preservation of alveolar bone and for correction of resorbed alveolar ridge for the placement of dental implants, alveolar bone grafting is done.

Methods of alveolar bone grafting are ridge preservation and ridge augmentation. Ridge preservation is done by grafting bony socket with an aim to preserve the remaining ridge volume inside the bony envelope. It is generally accomplished during tooth extraction with an "inlay" graft aiming to reduce loss of tissue after extraction of tooth.

Ridge augmentation is done by grafting of soft and hard tissues that aim to increase the alveolar ridge volume further than the present ridge volume. Usually done at areas having deficient alveolar bone.

\section{AIM OF BONE AUGMENTATION 3}

- Re-establish sufficient volume of bone for placement of implant.

- Re-establish intermaxillary ridge relationship.

- Confirm good aesthetic outcomes.

- Accomplish biomechanical requisites for prosthesis

- Provide strong bone for osseointegration and implant survival.

Augmentation of vertical ridge is a difficult task in reconstruction of the reduced maxilla and mandible arch height, as there is a necessity of soft tissue expansion and to create a proper bony architecture.

Augmentation of bone can be localized, or it can include the whole ridge which can be done by the following methods.

1. Onlay grafting- In this method to increase alveolar bone height or width, graft material is placed on top of the defect. This placed graft material is immobilized with the help of screws, plates or dental implants.

2. Inlay grafting- A portion of the alveolar bone is divided surgically, and the bone graft material is positioned in between the two sections.

3. Distraction osteogenesis- A gradual, controlled displacement of a surgically created bony segment. The two bony segments are gradually pulled apart, allowing new bone to form in the gap.

4. Guided bone regeneration (GBR)- A gap is maintained between the ridge and barrier membrane, allowing new bone to form within the gap.

A decision tree given by Plonka et al. 2018 was based on the amount of additional ridge height required. According to which if the ridge height needed is more than $6 \mathrm{~mm}$ then distracion osteogenesis should be performed in unpredictable and traumatic cases. ${ }^{4}$
Distraction Osteogenesis / Transosseous Synthesis / Osteodistraction is defined as

1. "A process of new bone formation between the surfaces of bone segments gradually separated by incremental traction" - Cope et al. (1999) ${ }^{5}$

2. "New bone tissue formation between osteotomized bone segments which are gradually separated by exerting an external force with the help of various distracting devices. The resulting callus tissue in the distraction gap will eventually mineralize, and a new bridge of bone tissue is formed between the osteotomy edges of the original bone segments". 6

\section{HISTORICAL ASPECTS}

- Fauchard (1728)7: - Applied compressive and tensile forces to the craniofacial skeleton for expansion of arch.

- Wescott (1859) ${ }^{8}$ : - First reported the application of mechanical forces on maxillary bones for correction of a cross-bite.

- Codvilla (1905) ${ }^{9}$ : - First clinical distraction was done to correct the limb length discrepancy.

- Ilizarov (1988) ${ }^{10}$ : - Conducted many studies and introduced technique for limb lengthening

- Wassmund, Rosenthal (1927)11: - Used intra oral tooth borne appliance and performed the first mandibular osteodistraction.

- McCarthy, colleagues (1989)12: - The first clinical extra oral distraction was done using Hoffmann Mini Lengthener in children with hemifacial microsomia and Nagers syndrome.

- Guerrero (1990)13: - Developed mid-symphyseal mandibular widening using an intraoral tooth borne hyrax - type device.

- Monasterio Molina (1999)14: - A technique was introduced for synchronized mandibular and maxillary distraction using mandibular devices alone.

- Cohen et al. (1995)15: - Performed first multi directional midface distraction, using buried Le fort III mid face advancement in 2 children with cleft lip and palate.

- Ortiz - Monasterio (1997)16: - First to use bidirectional device for osteodistraction of the mandible.

Alveolar distraction osteogenesis (ADO) is classified as unidirectional, bidirectional, horizontal and vertical ${ }^{17}$ Unidirectional ADO is done for vertical elongation of ridge, bidirectional ADO leads to simultaneous increase in vertical and sagittal vector, horizontal $\mathrm{ADO}$ is done when sagittal elongation is needed, and vertical ADO is done to increase height of the ridge.

\section{DISTRACTION TECHNIQUE}

The $1^{\text {st }}$ phase of the surgical procedure consists of flap elevation. A buccal paracrestal mucoperiosteal incision is performed preserving the crestal and lingual or palatal periosteum intact, permitting proper supply of blood. Next, the osteotomies are done, two vertical and one horizontal osteotomy cuts are given, to create a transport segment of 
trapezoidal shape, followed by a latency period of 7 days in which bone elongation begins. Then the elongation continues till the needed final bone height and volume is obtained. A consolidation period follows 3 to 4 months. Final procedure is removal of device after which endosseous dental implant placement is done followed by prosthetic rehabilitation. ${ }^{18}$ In severe bone deficiency due to trauma, reconstruction is done in 2 - stages in which bone block is placed followed by AD0. 19

\section{Stages of Alveolar Distraction Osteogenesis}

In the $1^{\text {st }}$ phase, known as the "osteotomy / surgical phase", cutting of bone is done, either partly (only through the hard exterior), or entirely, and a device is attached to be used in the next phases. In the $2^{\text {nd }}$ phase, known as "the latency period", which persists for 7 days, the device placed is not activated allowing early stages of bone healing. In the $3^{\text {rd }}$ phase, the "distraction phase", the device, which is attached to the bone on either side of the cut, separates the two pieces slowly with a rate of 1 or $0.5 \mathrm{~mm}$ per day, permitting to form new bone in the gap. When the needed length of the ridge is reached, which generally requires 3 to 7 days, a "consolidation phase" follows in which the device holds the bone in a steady position to let the bone to fully heal which usually last for 3 - 4 months. When the consolidation phase ends, the device is removed in a $2^{\text {nd }}$ surgical procedure.

\section{Span of the Defect ${ }^{21}$}

In case where the defect is large mesiodistally, it is difficult to retain a proper vector of elongation and transport segment stability is compromised. In such cases, to increase stability of the transport segment we can place two distractor devices at the sides of the defect, instead of one device placed at the centre of the defect. It is recommended to use 1 device if there are three to four teeth missing, and 2 devices if there are 4 or more teeth missing.

\section{Devices Used 18}

ADO devices is classified as

1. Extraosseous devices: These are the most commonly used devices.

Eg. "Alveolar ridge distractor; Synthes $®$, distractor track; KLS / Martin $\AA$, Tuttlingen, Germany".

2. Intraosseous distraction.

Eg. "LEAD $®$ System, Leibinger, Kalamazoo, MI; DIS - SIS distraction implant; SIS Systems Trade GmbH, Klagenfurt, Austria".

3. Distraction by implants: It needs ample basal bone for support.

\section{Indication $\mathrm{s}^{\mathbf{1 8}}$}

- Presence of more than $6 \mathrm{~mm}$ alveolar ridge deficiency.

- Deficiency of soft tissues for closure after augmentation of bone.

- Patients do not want $2^{\text {nd }}$ donor site for bone graft harvesting.

\section{Contraindications 18}

- Height of distraction segment is less than six mm
- Compromised periosteal palatal or lingual attachment to the distraction segment, thus compromising the supply of blood to that segment.

- Distraction segment has short bucco-lingual or buccopalatal width; thus elongation might cause segment fracture.

- Presence of less than two $\mathrm{mm}$ of bone in between the osteotomy site and the inferior alveolar nerve or sinus / nasal floor.

Advantages ${ }^{22-24}$

- Higher gain of bone when associated with other augmentation methods.

- Distraction of both soft and the hard tissues simultaneously.

- At the end of the process cortical bone and attached mucosa at the crest are left at the coronal aspect of the ridge, thus allowing for the placement of dental implants in the original attached mucosa and in cortical bone for increased stability.

- This procedure provides greater stability without involvement of donor site and lessen the rates of infection.

\section{Disadvantages ${ }^{22-24}$}

- There is a need of $2^{\text {nd }}$ surgery for removal of device (even though some suggest of immediate dental implant placement during device removal).

- There can be pain through the process of elongation, which can be reduced by controlling the elongation rate and extent of and by prescribing medications for pain.

\section{Complications and Management (Table 1) ${ }^{18}$}

\begin{tabular}{|c|c|c|}
\hline Sl. No. & Complications & Management \\
\hline 1 & $\begin{array}{l}\text { Inferior alveolar and mental } \\
\text { nerve injury }\end{array}$ & $\begin{array}{l}\text { Carefully perform flap elevation and } \\
\text { osteotomy }\end{array}$ \\
\hline 2 & $\begin{array}{l}\text { Compromised sector of } \\
\text { elongation } \\
\text { (The distraction segment is } \\
\text { susceptible to palatal or lingual } \\
\text { inclinations due to periosteal } \\
\text { tractions) }\end{array}$ & $\begin{array}{l}\text { Use elastics on teeth, short term anchorage } \\
\text { devices, or modified tooth born devices to } \\
\text { retain the proper elongation vector. }\end{array}$ \\
\hline 3 & $\begin{array}{l}\text { Fracture or malfunction of } \\
\text { device due to continuous } \\
\text { masticatory forces }\end{array}$ & Replacement of the device should be done. \\
\hline 4 & $\begin{array}{l}\text { Disclosure of the device can } \\
\text { cause infection or inappropriate } \\
\text { bony ossification. }\end{array}$ & $\begin{array}{l}\text { In such cases device removal should be } \\
\text { done. }\end{array}$ \\
\hline 5 & $\begin{array}{l}\text { Transport segment or basal } \\
\text { bone fracture }\end{array}$ & $\begin{array}{l}\text { 1. Proper use of equipment and precise } \\
\text { osteotomies should be done. } \\
\text { 2. In the case of fracture of the basal bone, } \\
\text { instant repositioning of bone surgically } \\
\text { and osteosynthesis are necessary. }\end{array}$ \\
\hline 6. & $\begin{array}{l}\text { Inappropriate vector of } \\
\text { elongation or position of rod } \\
\text { may interfere with occlusion }\end{array}$ & $\begin{array}{l}\text { Correct planning and placement of } \\
\text { distraction device should be done. }\end{array}$ \\
\hline 7 & Improper blood supply & Soft tissue management is necessary. \\
\hline \multicolumn{3}{|c|}{$\begin{array}{l}\text { Table 1. Complications and Management of } \\
\text { Alveolar Distraction Osteogenesis }\end{array}$} \\
\hline
\end{tabular}

Evidence Supporting Distraction Osteogenesis Elnayef et al. (2017) ${ }^{25}$ in their systematic review and meta analysis concluded that

1. If there is a need of $4 \mathrm{~mm}$ of vertical ridge augmentation, any method can be used if there are no local and systemic diseases. 
2. Highest vertical bone gain can be obtained by distraction osteogenesis and inlay block grafting, though these techniques also have higher rate of complication.

3. GBR is the most dependable technique for bone stability as there is less resorption and lesser complication and morbidity rate.

4. Regardless of the method used, survival of implant and rates of success in the augmented region are high in the short term assessment.

Hasan et al. (2019) ${ }^{26}$ in his systematic review and metaanalysis concluded that

1. DO was not superior to block grafting for vertical bone gain.

2. No significant difference was obtained between DO and block grafting for mean loss of bone.

3. Both methods showed number of complications.

\section{CONCLUSIONS}

Alveolar distraction osteogenesis is a technique sensitive process, affective in gaining bone height in areas having ridge defect more than $6 \mathrm{~mm}$ and its ability to increase soft tissue along with hard tissue is additional benefit of this technique. For successful outcomes of this technique appropriate selection of case, proper treatment planning and patient's cooperation is important. Clinician should be aware of the limitations and possible complications of this procedure. ${ }^{18}$

Financial or other competing interests: None.

Disclosure forms provided by the authors are available with the full text of this article at jemds.com.

\section{REFERENCES}

[1] Adell R, Lekholm U, Rockler B, et al. A 15 - year study of osseointegrated implants in the treatment of the edentulous jaw. Int J Oral Surg 1981;10(6):387-416.

[2] Den Hartog L, Slater JJ, Vissink A, et al. Treatment outcome of immediate, early and conventional single - tooth implants in the aesthetic zone: a systematic review to survival, bone level, soft - tissue, aesthetics and patient satisfaction. J Clin Periodontol 2008;35(12):1073-86.

[3] Daga D, Mehrotra D, Mohammad S, et al. Tentpole technique for bone regeneration in vertically deficient alveolar ridges: a review. J Oral Biol Craniofac Res 2015;5(2):92-7.

[4] Plonka AB, Urban IA, Wang HL. Decision tree for vertical ridge augmentation. Int J Periodontics Restorative Dent 2018;38(2):269-75.

[5] Cope JB, Samchukov ML, Cherkashin AM, et al. Biomechanics of mandibular distractor orientation: an animal model analysis. J Oral Maxillofac Surg 1999;57(8):952-62; discussion 963-4.

[6] Hegab AF, Shuman MA. Distraction osteogenesis of the maxillofacial skeleton: biomechanics and clinical implications. Open Access Scientific Reports 2012;1(11):509.

[7] Steiner CC. Is there one best orthodontic appliance? The Angle Orthodontist 1933;3(4):277-98.
[8] Westcott A. A case of irregularity. Philadelphia: SS White Dental Manufacturing Company, 1859.

[9] Codivilla A. On the means of lengthening, in the lower limbs, the muscles and tissues which are shortened through deformity. Am J Orthop Surg 1905;2(4):353-69.

[10] Ilizarov GA. The principles of the Ilizarov method. Bull Hosp Joint Dis Orthop Inst 1988;48(1):1-11.

[11] Wassmund M. Textbook of Practical Surgery of the Mouth and Jaw. Vol. 1. Meusser 1935: p. 282.

[12] McCarthy JG, Schreiber J, Karp N, et al. Lengthening the human mandible by gradual distraction. Plast Reconstr Surg 1992;89(1):1-8; discussion 9-10.

[13] Guerrero CA. Expansion rapida mandibular. Rev Venez Ortod 1990;12:48.

[14] Molina F, Monasteiro OF. Mandibular elongation and remodeling by distraction: a farewell to major osteotomies. Plastic Reconstr Surg 1995;96(4):825-40; discussion 841-2.

[15] Cohen SR, Rutrick RE, Burstein FD. Distraction osteogenesis of the human craniofacial skeleton: initial experience with new distraction system. J Craniofac Surg 1995;6(5):368-74

[16] Monasteiro OF, Molina F, Andrade L, et al. Simultaneous mandibular and maxillary distraction in hemifacial microsomia in adults: avoiding occlusal disasters. Plast Reconstr Surg 1997;100(4):852-61.

[17] Chhikara N, Shaik S, Bhargava S. Review on distraction osteogenesis: a boon to maxillofacial reconstruction. Int J Appl Dent Sci 2018;4(2):44-8.

[18] Renapurkar S, Troulis MJ. Alveolar distraction osteogenesis for vertical ridge augmentation: surgical principles and technique. Vertical alveolar ridge augmentation in implant dentistry: a surgical manual. Hoboken, New Jersey: John Wiley \& Sons, Inc., 2016;22:222-8.

[19] Tolstunov L, Hamrick JFE, Broumand V, et al. Bone augmentation techniques for horizontal and vertical alveolar ridge deficiency in oral implantology. Oral Maxil Surg Clin North Am 2019;31(2):163-91.

[20] Rachmiel A, Emodi O, Aizenbud D, et al. Two - stage reconstruction of the severely deficient alveolar ridge: bone graft followed by alveolar distraction os - teogenesis. Int J Oral Maxillofac Surg 2018;47(1):117-24.

[21] Rachmiel A, Shilo D, Aizenbud D, et al. Three- dimensional reconstruction of post - traumatic defi - cient anterior maxilla. J Oral Maxillofac Surg 2017;75(12):2689-700.

[22] Rachmiel A, Srouji S, Peled M. Alveolar ridge augmentation by distraction osteogenesis. Int J Oral Maxillofac Surg 2001;30(6):510-7.

[23] Jensen OT, Cockrell R, Kuhike L, et al. Anterior maxillary alveolar distraction osteogenesis: a pro - spective 5 - year clinical study. Int J Oral Maxillofac Implants 2002;17(1):52-68.

[24] Jensen OT, Ueda M, Laster Z, et al. Alveolar distraction osteogenesis. Quintessence 2002.

[25] Elnayef B, Monje A, Gargallo - Albiol J, et al. Vertical ridge augmentation in the atrophic mandible: a systematic review and meta-analysis. Int $\mathrm{J}$ Oral Max Impl 2017;32(2):291-312.

[26] Hameed MH, Gul M, Ghafoor R, et al. Vertical ridge gain with various bone augmentation techniques: a systematic review and meta-analysis. J Prosthodont 2019;28(4):4217. 